\title{
THE SPATIAL DISTRIBUTION OF PERCH (PERCA FLUVIATILIS) ECTOPARASITES AND THE EFFECT OF CHEMICAL WATER QUALITY PARAMETERS ON ECTOPARASITE SPATIAL NICHE SIZE
}

\author{
Maksims Zolovs ${ }^{1, \#}$, Madara Priekule ${ }^{1}$, Olesia Gasperovich ${ }^{1}$, Jelena Kolesnikova ${ }^{1}$, \\ Sergejs Osipovs ${ }^{1}$, and Voldemārs Spunǵgis ${ }^{2}$ \\ ${ }^{1}$ Institute of Life Sciences and Technology, Daugavpils University, 1a Parādes Str., Daugavpils, LV-5401, LATVIA, \\ ${ }^{2}$ Department of Zoology and Animal Ecology, Faculty of Biology, University of Latvia, 1 Jelgavas Str., Rīga, LV-1004, LATVIA \\ \# Corresponding author, maksims.zolovs@du.Iv
}

Communicated by Arvīds Barševskis

\begin{abstract}
Seasonal changes of abiotic factors and their influence on parasite occurrence have repeatedly been studied. Most of the studies have been conducted to evaluate the effect of water physicochemical parameters on changes in the intensity of infection, prevalence and component community of a number of parasite species. However, insufficient attention has been paid to the link between water quality parameters and spatial niche size of ectoparasites. The distribution of ectoparasite species on perch (Perca fluviatilis L.) was studied to establish whether seasonal changes of water quality parameters are associated with ectoparasite spatial niche size. The concentration of phosphates $\left(\mathrm{PO}_{4}^{3-}\right)$, nitrates $\left(\mathrm{NO}_{3}^{-}\right)$, sulphates $\left(\mathrm{SO}_{4}^{2-}\right)$ and dissolved oxygen $(\mathrm{DO})$ in the water of Lake Sila (Latvia) was measured every month throughout the year and recorded all ectoparasites on perch. Zero-inflated mixed models were used to evaluate which of the water parameters influence the spatial niche size of ectoparasites. Our findings showed that spatial niche size of some ectoparasite species is affected by a set of water quality parameters and that this effect is negative. The spatial niche size of Anodonta cygnea was negatively associated with phosphate, nitrate, sulphate and dissolved oxygen concentration. The spatial niche size of Ancyrocephalus percae was negatively associated with sulphate, and the spatial niche size of Ergasilus sieboldi was negatively associated with nitrate concentration.
\end{abstract}

Key words: perch, ectoparasites, niche size model, boreal lake, water parameters, Latvia.

\section{INTRODUCTION}

Host and water environments influence the presence and abundance of fish parasites. However, the strength of this influence may vary between ectoparasites and endoparasites. Higher susceptibility to changes in the aquatic environment is expected for ectoparasites because they require physiological adaptation and tolerance similar to that of their host, whereas endoparasites are more susceptible to changes in homeostasis of the host and changes associated with the life cycle of this host (maturation, migration, breeding, etc.) (Willmer et al., 2004).

A parasite's habitat is made up of a variety of biotic and abiotic factors. Abiotic factors are physicochemical components (temperature, $\mathrm{pH}$, light intensity, salinity), whereas biotic factors are usually associated with the host (age, sex, length, immune response) (Dogel, 1962; Poulin, 2004;
2008; Morand and Krasnov, 2010). Seasonal changes of abiotic factors and their influence on parasite occurrence have been the focus of many ecological studies (Öztürk and Altunel, 2006; Lamková et al., 2007; Khidr et al., 2012; Majumder et al., 2013; Wali et al., 2016). For example, prevalence and intensity of parasitic infection have been evaluated considering several parameters of water quality (temperature, dissolved oxygen, free $\mathrm{CO}_{2}$, alkalinity, hardness, clarity) and water pollutants (heavy metals, petrochemicals, effluents, organic pollutants) (Siddall et al., 1997; Yeomans et al., 1997; Faulkner and Lochmiller, 2000; Lefcort et al., 2002; Billiard and Khan, 2003). An increase in the prevalence and abundance for some parasite species, and decrease for the other species to these factors have been observed (Sures, 2004). Meta-analysis of the 52 studies showed that responses of parasites to stressors are not equal (Vidal-Martínez et al., 2010). 
While the effect of stressors on parasite's prevalence, intensity of infection, abundance and component community has repeatedly been studied (see reviews of Gilbert and Avenant-Oldewage (2017) and Sures et al. (2017), insufficient attention has been paid to the link between water quality parameters and spatial niche size of ectoparasites.

Several natural and/or anthropogenic sources may increase concentration of phosphates $\left(\mathrm{PO}_{4}^{3-}\right)$, nitrates $\left(\mathrm{NO}_{3}^{-}\right)$, sulphates $\left(\mathrm{SO}_{4}^{2-}\right)$ to a level toxic for some aquatic organisms (Kutty, 1987; Shen et al., 2013). The association between the abundance of parasites and phosphate, nitrate, and sulphate ion concentration has rarely been studied or evaluated indirectly since most of the ion concentrations are related to the trophic state of a lake. Although eutrophication of a lake is a slow natural process, the concentration of those parameters depends on many factors, which markedly fluctuate throughout the year (Shen et al., 2013). Also, parasite abundance fluctuates throughout the year and is associated with some water quality parameters (Vidal-Martínez et al., 2010).

The aim of this study was to evaluate spatial distribution of perch ectoparasites, measure chemical water quality parameters in each month throughout the year, and to test whether seasonal changes of water quality parameters are associated with ectoparasite spatial niche size. To answer this question we measured the concentration of phosphates, nitrates, sulphates and dissolved oxygen in the water of Lake Sila (Latvia) every month throughout the year and recorded the distribution of ectoparasites on perch (Perca fluviatilis L.). We expected that ectoparasites will show specific response to the set of water quality parameters. Our expectations were mainly based on the findings of Vidal-Martínez et al. (2010) that the concentration of water quality parameters were positively associated with spatial niche size of protists, negatively with crustaceans and glochidians, and were not associated with monogeneans. The relationship between physical water quality variables (for example, temperature) and parasite infection parameters has been addressed in a number of studies (Harvell, 1999; 2002; Marcogliese, 2001; Retief et al., 2007; Blažek et al., 2008). Therefore, the present investigation focuses only on relationships between ion concentrations and niche breadth of ectoparasites.

\section{MATERIALS AND METHODS}

Investigated waterbody. Lake Sila $\left(55^{\circ} 44^{\prime} 07.0^{\prime \prime} \mathrm{N}\right.$ $26^{\circ} 47^{\prime} 34.0^{\prime \prime} \mathrm{E}$ ) is a small lake with surface area 262.0 ha and mean depth $4.1 \mathrm{~m}$. It lies within the nature park "Silene" in Latvia (Fig. 1). It has a flow-through hydrological regime: two rivers and streams enter the lake and one river flows out (Tidrikis, 1998).

Collecting of water samples and quality analysis. Water samples were collected every month from June 2015 to May 2016. Overall, a total of 60 (5 per month) surface grab water samples were collected using 21 polythelene bottles. All samples were stored and stabilised according to ISO (Inter- national Organization for Standardization), delivered to the laboratory and examined on the same day of collection. Phosphate, nitrate and sulphate ions were measured with the spectrophotometry according to ISO standards: ISO 6878:2005; ISO 7890-3:2002 and ISO 9280:1990. Dissolved oxygen concentration of water was measured by titration according to ISO 8467:1995.

Collecting and examination of perch and ectoparasites. The necessary fish individuals needed to estimate association between seasonal changes of water quality parameters and ectoparasite spatial niche size were calculated with G*Power 3 (Faul et al., 2007; 2009). The following parameters were used: number of predictors $=5$, power $(1-\beta$ error probability $)=0.95, \alpha$ error probability $=0.05$ and effect size $\mathrm{f} 2=0.15$ (correspond to medium effect size). Output parameters showed that for this study the necessary minimum total sample size was 138 fish individuals.

Perch were collected from Lake Sila every month $(\sim 12$ individuals) throughout the year. In total, 149 fish were captured by fishing rod and gill nets (total length of fish $16.8 \pm$ 5.0 , mean $\pm \mathrm{SD}$ ) and examined on the same day of collection. Before examination fish were euthanised according to Algers et al. (2009). Gill apparatus, fins, surface, and the nasal and oral cavities were examined of each side of each fish. Gill arches were numbered from the anterior to the posterior as 1-4. Each arch was divided into three sectors from the dorsal to the ventral end as I-III (Simková et al., 2000; Zolovs et al., 2016). Fins were examined as follow: D - dorsal fin, C - caudal fin, A - anal fin, Pc - pectoral fins and $\mathrm{Pl}-$ pelvic fins and scraped mucus from the entire surface, and the nasal and oral cavities. All ectoparasites were counted and identified to species level using microscopy and identification keys (Sulman, 1984; Gussev, 1985; Bauer, 1987).

There are a number of niche concepts. We used the Hutchinsonian niche concept that is defined as an "n-dimensional hypervolume", where the dimensions are environmental conditions and resources (Hutchinson, 1957). However, in the present study, we examine only one dimension and use the term 'niche' as a synonym of space occupied (spatial unit on host occupied by ectoparasites).

Statistical data analysis. The Kruskal-Wallis test was conducted to determine if there were differences between months for concentration of water quality parameters and niche breadth of parasites. The chi-square test was used to test whether a parasite prefers certain a localisation over others. Those tests were carried out using SPSS Statistics version 22 (IBM Corporation, Chicago, Illinois). Parasite counts often have highly skewed distribution with an excessive number of zeroes. To cope with this, zero-inflated mixed modelling was applied (Pilosof et al., 2012; Barnard et al., 2015). To account for a large number of zeroes in our data, we applied zero-inflated Poisson (ZIP) or zero-inflated negative binomial (ZINB) mixed models to test for the effects of phosphate, nitrate, sulphate and dissolved oxygen concentration on the count and niche breadth of ecto- 

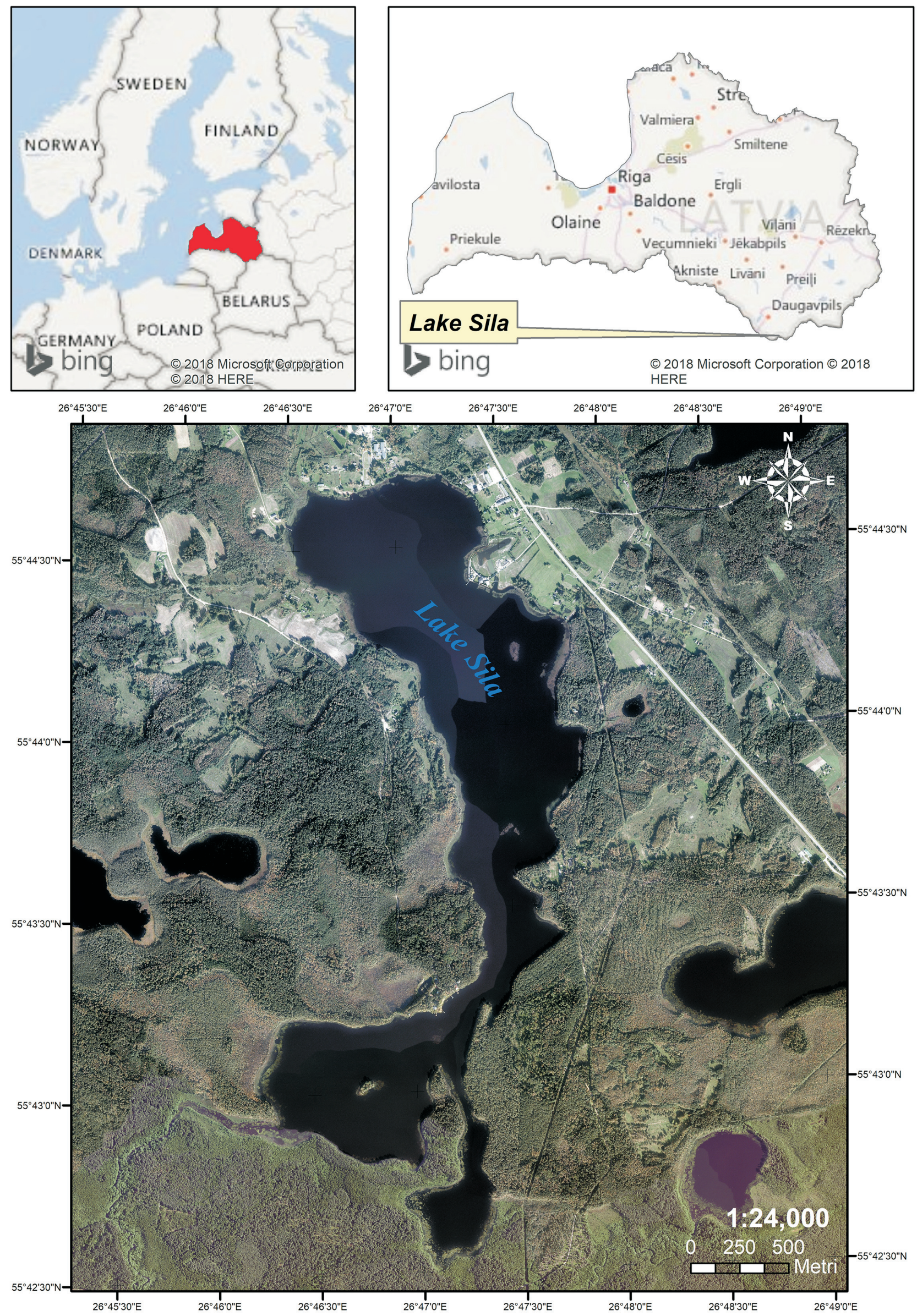

Fig. 1. Location of Lake Sila. 
parasites. Fish total length was added in the analysis due to the influence of this parameter on parasite counts (Cardon et al., 2011). For each species, we ran two models (negative binomial and Poisson distribution) using a "psc)" package (Jackman, 2015) implemented in R ( R Development Core Team, 2016). Akaike Information Criterion (AIC) was used to select the best model for each data set. The significance of the estimated coefficients was tested against a reference level that was chosen arbitrarily among five-factor levels (phosphate, nitrate, sulphate, and dissolved oxygen concentration and fish length). To have all explanatory variables (predictors) in comparable scales, data were scaled by the standard deviation method. Only weakly inter-correlated water quality parameters were included in the models.

Standardised Levin's niche breadth was calculated according to Krebs (1998), where $p_{i}$ is a proportion of individuals found in the localisation $i$, and $n$ is the number of possible localisations. Overall, a total of 34 localisations were used to calculate Levin's niche breadth. The standardised Levin's index ranges from 0 to 1 , where 0 indicates the absence of a species and 1 indicates that a species occupies all available localisations.

\section{RESULTS}

Data on parasite count and water quality parameters at each month are presented in Table 1 . In total, we recorded 2822 parasite individuals belonging to one protist species (Trichodina sp.) and six metazoan species (Ancyrocephalus percae, Anodonta cygnea, Unio sp., Achtheres percarum, Argulus foliaceus and Ergasilus sieboldi). The mean niche breadths of metazoan ectoparasites on perch in each month are presented in Table 2. The Kruskal-Wallis test showed that niche breadths differed between sampling months only for A. cygnea $\mathrm{X}^{2}(5)=16.846, p=0.005$. Data on parasite count within gill apparatus, fins, body surface, nasal and oral cavities are presented in Tables 3 and 4. The chi-square test showed that A. cygnea, Unio sp., A. percarum and E. sieboldi $(p<0.05)$ preferred a specific localisation, whereas $A$. percae and A. foliaceus $(p>0.05)$ were randomly distributed.

The concentration of phosphates, nitrates, sulphates and dissolved oxygen differed between sampling months $(p<$ $0.05)$. The monthly variation in the concentration of phosphate $(\mathrm{CV}$ (coefficient of variation) $=94.3 \%$ ) and nitrate $(\mathrm{CV}=139.3 \%)$ in the lake was at least two times higher than the concentration of sulphate ions $(\mathrm{CV}=36.9 \%)$ and dissolved oxygen $(\mathrm{CV}=11.2 \%)(p<0.05)$.

Zero-inflated models showed that niche breadth of three ectoparasite species was negatively associated with water quality parameters and positively associated with fish length (Table 5). We observed that only fish length might generate false zeros for niche breadth. Our findings showed that the spatial niche size of A. cygnea was negatively associated with phosphate, nitrate, sulphate and dissolved oxygen concentration. The spatial niche size of $A$. percae was negatively associated with sulphate concentration, and the spatial niche size of E. sieboldi was negatively associated with nitrate concentration.

\section{DISCUSSION}

Our main expectations were supported only partly because data showed that not all ectoparasite species responded to the phosphate, nitrate, sulphate and dissolved oxygen con-

Table 1

MEAN VALUES OF WATER QUALITY PARAMETERS AND MEAN PARASITE COUNTS ON PERCH (PERCA FLUVIATILIS) FROM LAKE SILA IN EACH MONTH (LATVIA)

\begin{tabular}{|c|c|c|c|c|c|c|c|c|c|c|}
\hline & $\mathrm{SO}_{4}^{2-} \mathrm{mg} \mathrm{l}^{-1}$ & $\mathrm{PO}_{4}^{3-} \mathrm{mg} \mathrm{l}^{-1}$ & $\mathrm{NO}_{3}^{-} \mathrm{mg}^{-1}$ & $\mathrm{DO} \mathrm{mg} \mathrm{l}^{-1}$ & \begin{tabular}{|c} 
Ancyrocepha- \\
lus percae
\end{tabular} \mid & $\begin{array}{c}\text { Anodonta } \\
\text { cygnea }\end{array}$ & Unio sp. & $\begin{array}{l}\text { Achtheres } \\
\text { percarum }\end{array}$ & $\begin{array}{l}\text { Argulus } \\
\text { foliaceus }\end{array}$ & $\begin{array}{c}\text { Ergasilus } \\
\text { sieboldi }\end{array}$ \\
\hline June & 6.0901 & 0.0099 & 0.0253 & 6.68 & 2 & & 65 & & 1 & 2 \\
\hline July & 8.8889 & 0.0043 & 0.0008 & 7.64 & & & 35 & & & 2 \\
\hline August & 10.8890 & 0.0084 & 0.0099 & 6.76 & 1 & & 13 & 1 & & 3 \\
\hline September & 8.8943 & 0.0214 & 0.1537 & 5.95 & 2.5 & & & 1 & 1 & 3 \\
\hline October & 7.9024 & 0.0354 & 0.0167 & 6.73 & 1.5 & 1 & & 1 & 1 & 7 \\
\hline November & 4.2469 & 0.0062 & 0.0026 & 6.03 & 3 & 5 & & 1 & & 7 \\
\hline December & 5.3097 & 0.0167 & 0.0154 & 5.07 & 2 & 6 & & & & 1.5 \\
\hline January & 7.9370 & 0.0281 & 0.0537 & 6.80 & 2 & 2 & & & 1 & \\
\hline February & 5.2759 & 0.0317 & 0.0205 & 6.23 & & 8 & & & & 1.5 \\
\hline March & 8.9091 & 0.0234 & 0.0758 & 6.51 & 1.5 & 4 & & & & \\
\hline April & 10.8870 & 0.0053 & 0.0341 & 7.01 & & 6 & & & & \\
\hline Range & 13.945 & 0.085 & 0.245 & 3.150 & 2 & 13 & 79 & 1 & 1 & 6 \\
\hline Mean & 7.931 & 0.018 & 0.034 & 6.502 & 2 & 5.8 & 51.3 & 1 & 1 & 3 \\
\hline $\mathrm{SD}$ & 2.929 & 0.017 & 0.048 & 0.728 & 0.6 & 4 & 34.5 & 1 & 1 & 2 \\
\hline Prevalence, $\%$ & & & & & 23 & 42 & 21 & 9 & 7 & 33 \\
\hline
\end{tabular}

DO, dissolved oxygen; SD, standard deviation 
MEAN NICHE BREADTH OF ECTOPARASITES ON PERCH (PERCA FLUVIATILIS) FROM LAKE SILA IN EACH MONTH (LATVIA)

\begin{tabular}{|c|c|c|c|c|c|c|}
\hline & $\begin{array}{c}\text { Ancyrocephalus } \\
\text { percae }\end{array}$ & Anodonta cygnea & Unio sp. & Achtheres percarum & Argulus foliaceus & Ergasilus sie boldi \\
\hline June & 0.03 & & 0.37 & & 0.03 & 0.11 \\
\hline July & & & 0.22 & & & 0.09 \\
\hline August & & & 0.12 & & & 0.08 \\
\hline September & 0.06 & & & & & 0.09 \\
\hline October & 0.03 & & & 0.03 & & 0.14 \\
\hline November & 0.07 & 0.10 & & & & 0.13 \\
\hline December & 0.03 & 0.04 & & & & 0.03 \\
\hline January & 0.04 & 0.04 & & 0.01 & 0.01 & \\
\hline February & & 0.11 & & & & 0.02 \\
\hline March & & 0.12 & & & & \\
\hline April & & 0.17 & & & & \\
\hline May & & 0.24 & 0.37 & & & \\
\hline
\end{tabular}

Table 3

DISTRIBUTION OF PARASITE SPECIES WITHIN GILL APPARATUS OF PERCH (PERCA FLUVIATILIS) FROM LAKE SILA (LATVIA)

\begin{tabular}{|c|c|c|c|c|c|c|}
\hline \multirow[t]{2}{*}{ Species } & \multirow[t]{2}{*}{ Arch } & \multirow[t]{2}{*}{ Side } & \multicolumn{3}{|c|}{ Sectors of arch } & \multirow[t]{2}{*}{ Total } \\
\hline & & & $\mathrm{I}$ & II & III & \\
\hline \multirow{8}{*}{$\begin{array}{l}\text { Ancyrocephalus } \\
\text { percae }\end{array}$} & 1 & $\mathrm{R}$ & 3 & 5 & 4 & 12 \\
\hline & & $\mathrm{L}$ & 2 & 3 & 7 & 12 \\
\hline & 2 & $\mathrm{R}$ & 1 & 3 & 8 & 12 \\
\hline & & $\mathrm{L}$ & 2 & 5 & 5 & 12 \\
\hline & 3 & $\mathrm{R}$ & 1 & 3 & 2 & 6 \\
\hline & & $\mathrm{L}$ & 4 & 0 & 3 & 7 \\
\hline & 4 & $\mathrm{R}$ & 0 & 1 & 3 & 4 \\
\hline & & $\mathrm{L}$ & 1 & 0 & 3 & 4 \\
\hline \multirow{8}{*}{$\begin{array}{l}\text { Anodonta } \\
\text { cygnea }\end{array}$} & 1 & $\mathrm{R}$ & 18 & 16 & 12 & 46 \\
\hline & & $\mathrm{L}$ & 15 & 23 & 13 & 51 \\
\hline & 2 & $\mathrm{R}$ & 11 & 29 & 19 & 59 \\
\hline & & $\mathrm{L}$ & 12 & 27 & 24 & 63 \\
\hline & 3 & $\mathrm{R}$ & 11 & 22 & 18 & 51 \\
\hline & & $\mathrm{L}$ & 16 & 28 & 9 & 53 \\
\hline & 4 & $\mathrm{R}$ & 3 & 9 & 2 & 14 \\
\hline & & $\mathrm{L}$ & 0 & 16 & 2 & 18 \\
\hline \multirow[t]{8}{*}{ Unio sp. } & 1 & $\mathrm{R}$ & 43 & 96 & 65 & 204 \\
\hline & & $\mathrm{L}$ & 44 & 76 & 40 & 160 \\
\hline & 2 & $\mathrm{R}$ & 84 & 135 & 90 & 309 \\
\hline & & $\mathrm{L}$ & 79 & 125 & 61 & 265 \\
\hline & 3 & $\mathrm{R}$ & 58 & 96 & 79 & 233 \\
\hline & & $\mathrm{L}$ & 80 & 103 & 60 & 243 \\
\hline & 4 & $\mathrm{R}$ & 34 & 58 & 35 & 127 \\
\hline & & $\mathrm{L}$ & 35 & 54 & 43 & 132 \\
\hline
\end{tabular}

\begin{tabular}{|c|c|c|c|c|c|c|}
\hline \multirow{2}{*}{ Species } & \multirow[t]{2}{*}{ Arch } & \multirow[t]{2}{*}{ Side } & \multicolumn{3}{|c|}{ Sectors of arch } & \multirow[t]{2}{*}{ Tota } \\
\hline & & & I & II & III & \\
\hline \multirow{8}{*}{$\begin{array}{l}\text { Achtheres } \\
\text { percarum }\end{array}$} & \multirow[t]{2}{*}{1} & $\mathrm{R}$ & 7 & 0 & 0 & 7 \\
\hline & & $\mathrm{L}$ & 6 & 1 & 0 & 6 \\
\hline & \multirow[t]{2}{*}{2} & $\mathrm{R}$ & 0 & 0 & 1 & 1 \\
\hline & & $\mathrm{L}$ & 0 & 1 & 0 & 1 \\
\hline & \multirow[t]{2}{*}{3} & $\mathrm{R}$ & 0 & 0 & 0 & 1 \\
\hline & & $\mathrm{L}$ & 0 & 0 & 0 & 0 \\
\hline & \multirow[t]{2}{*}{4} & $\mathrm{R}$ & 0 & 0 & 0 & 0 \\
\hline & & $\mathrm{L}$ & 0 & 0 & 0 & 0 \\
\hline \multirow{8}{*}{$\begin{array}{l}\text { Argulus } \\
\text { foliaceus }\end{array}$} & \multirow[t]{2}{*}{1} & $\mathrm{R}$ & 0 & 0 & 0 & 0 \\
\hline & & $\mathrm{L}$ & 1 & 0 & 0 & 1 \\
\hline & \multirow[t]{2}{*}{2} & $\mathrm{R}$ & 0 & 1 & 0 & 1 \\
\hline & & $\mathrm{L}$ & 0 & 1 & 1 & 2 \\
\hline & \multirow[t]{2}{*}{3} & $\mathrm{R}$ & 0 & 1 & 0 & 1 \\
\hline & & $\mathrm{L}$ & 0 & 0 & 0 & 0 \\
\hline & \multirow[t]{2}{*}{4} & $\mathrm{R}$ & 0 & 0 & 1 & 1 \\
\hline & & $\mathrm{L}$ & 0 & 0 & 0 & 0 \\
\hline \multirow{8}{*}{$\begin{array}{l}\text { Ergasilus } \\
\text { sieboldi }\end{array}$} & \multirow[t]{2}{*}{1} & $\mathrm{R}$ & 7 & 4 & 7 & 18 \\
\hline & & $\mathrm{L}$ & 6 & 7 & 9 & 22 \\
\hline & \multirow[t]{2}{*}{2} & $\mathrm{R}$ & 11 & 9 & 8 & 28 \\
\hline & & $\mathrm{L}$ & 10 & 16 & 15 & 42 \\
\hline & \multirow[t]{2}{*}{3} & $\mathrm{R}$ & 15 & 9 & 6 & 30 \\
\hline & & $\mathrm{L}$ & 16 & 3 & 12 & 31 \\
\hline & \multirow[t]{2}{*}{4} & $\mathrm{R}$ & 9 & 12 & 3 & 24 \\
\hline & & $\mathrm{L}$ & 13 & 10 & 7 & 30 \\
\hline
\end{tabular}

The number of specimens found in given sector in all fish examined throughout the year.

centration. We recorded only negative association between niche breadth and water parameters for some species. However, our additional expectation according to Cardon et al. (2011) was supported because we found a positive association between niche breadth and fish length.

Usually, the spatial niches of ectoparasites are restricted and the parasite niches are segregated between species (Morand

et al., 2015). However, Rohde (1991) showed that it is not influenced by the presence of competing species. The low density of parasite individuals and resource richness in the host prevent parasite interaction.

The association between parasite niche breadth and water parameters might be not strongly linear. For example, nitrates and phosphates are two nutrients of primary concern 
DISTRIBUTION OF PARASITE SPECIES ON FINS, BODY SURFACE, NASAL AND ORAL CAVITIES OF PERCH (PERCA FLUVIATILIS) FROM LAKE SILA (LATVIA)

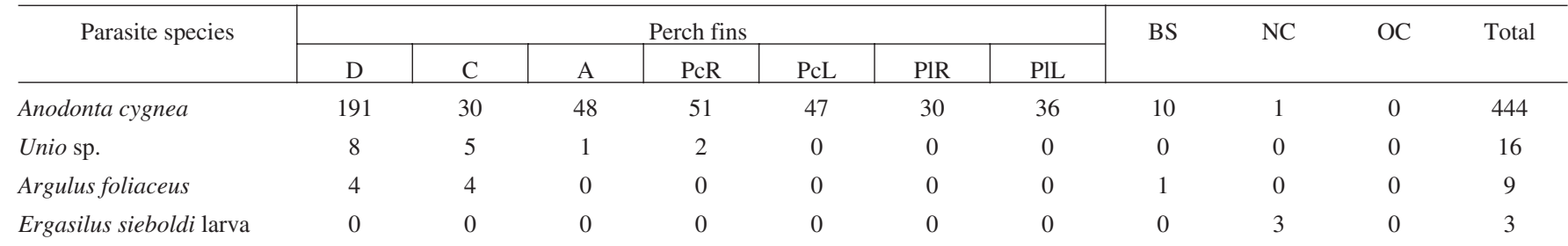

D, dorsal fin; C, caudal fin; A, anal fin; PcR, pectoral fin right side; PcL, pectoral fin left side; PIR, pelvic fin rigth side; PIL, pelvic fin left side; BS, body surface; NC, nasal cavity; OC, oral cavity. Number of specimens found in given sector in all fish examined throughout the year.

Table 5

SUMMARY OF ZERO-INFLATED MODELS OF FACTORS SIGNIFICANTLY AFFECTING NICHE BREADTH OF ECTOPARASITES ON PERCH (PERCA FLUVIATILIS)

\begin{tabular}{|c|c|c|c|c|c|c|}
\hline Parasite species & Model & Mean niche breadth & Factors & $\begin{array}{c}\text { Estimated coefficient } \\
\pm \mathrm{SE}\end{array}$ & $\mathrm{Z}$ value & $\mathrm{p}$ \\
\hline \multirow{3}{*}{$\begin{array}{l}\text { A. cygnea } \\
\text { count model }\end{array}$} & \multirow[t]{3}{*}{ ZINB } & \multirow[t]{3}{*}{0.04} & phosphates & $-0.70 \pm 0.25$ & 2.76 & 0.005 \\
\hline & & & nitrates & $-2.97 \pm 0.41$ & -7.09 & $<0.001$ \\
\hline & & & oxygen & $-2.78 \pm 0.51$ & -5.44 & $<0.001$ \\
\hline
\end{tabular}

A. cygnea

zero inflation

\begin{tabular}{lccccc}
\hline $\begin{array}{l}\text { A. percae } \\
\text { count model }\end{array}$ & ZINB & 0.01 & sulphates & $-1.18 \pm 0.42$ & 0.004 \\
$\begin{array}{l}\text { A. percae } \\
\text { zero inflation }\end{array}$ & & fish length & $-7.54 \pm 3.61$ & -2.83 \\
\hline $\begin{array}{l}\text { E. sieboldi } \\
\text { count model }\end{array}$ & ZINB & 0.02 & nitrates & $-0.47 \pm 0.22$ & -2.08 \\
fish length & & $1.30 \pm 0.19$ & 0.03 \\
\hline
\end{tabular}

E. sieboldi

zero inflation

ZIP, zero-inflated Poisson mixed model; ZINB, zero-inflated negative binomial mixed model. Results are shown only for models with significant coefficients.

in lakes. They may benefit some organisms up to a specific concentration, above which toxicity might occur. For example, Johnson et al. (2007) provided experimental evidence that eutrophication promotes parasite infection in amphibians. However, the enrichment of nitrate concentration was shown to reduce ectoparasite Gyrodactylus turnbulli infection intensity in Trinidadian guppies (Poecilia reticulate) (Smallbone et al., 2016). Sulphate ions are an essential plant nutrient and are not considered toxic to animals (Zhou, 1989). However, our findings showed that sulphate concentration was negatively associated with ectoparasite niche breadth.

Oxygen plays a crucial role in various biochemical and physiological processes of many organisms. For example, parasites use oxygen for energy production and oxidative catabolism and anabolism (Moulder, 1950). However, the oxygen concentration in water at a high or low level may harm aquatic organisms. Organic decomposition and respiration of aquatic organisms decrease oxygen concentrations, whereas photosynthesis and aeration contribute to supersaturation of water (Shen et al., 2013). Eutrophication-induced reduction in dissolved oxygen may cause hypoxic stress in many aquatic organisms (Vaquer-Sunyer and Duarte, 2008). For example, hypoxic stress may promote release of the parasitic glochidia from Unio mussels (Aldridge and McIvor, 2003). The minimal requirements of oxygen concentration have been studied for many fish species. For example, the lower optimum limit of dissolved oxygen concentration for perch is $5 \mathrm{mg} \cdot \mathrm{l}^{-1}$ (Krieger et al., 1983). Our data show that oxygen concentration in Lake Sila may drop to the lower optimal limit for perch $\left(\min \mathrm{DO}=5.01 \mathrm{mg} \cdot \mathrm{l}^{-1}\right)$. However, the minimal requirements of oxygen concentration for parasites are unknown. Oxygen concentration on the bottom of lake drops even lower, which may influence development of parasite eggs. Saunders et al. (2000) found that availability of oxygen plays a significant role in the embryonation of parasite eggs. Some studies have recorded an association between oxygen concentration in water and ectoparasite spatial preferences. For example, Chapman et al. (2000) studied the prevalence and intensity of the gill monogenean Neodiplozoon polycotyleus Paperna in cyprinid fish from oxygen-poor waters (mean $2.5 \mathrm{mg} \cdot \mathrm{l}^{-1}$ ) and noted that site specificity of parasites on gills may be related to oxygen availability. 
In conclusion, the relationship between water quality and spatial niche breadth of ectoparasites is likely to be variable and more complex than reported here. We suggest that changes in spatial niche breadth of ectoparasites are not solely due to changes in water chemical variables. A number of several physical parameters (such as temperature, $\mathrm{pH}$ and salinity) and biotic factors (such as parasite intensity of infection, host sex and age) may operate in synergy with water chemical variables. However, the analysis of all mentioned variables requires a significantly larger sample size (number of examined fish individuals) and perhaps should be analysed as a meta-analysis. Nevertheless, our study shows that seasonal changes of water chemical parameters in the lake are enough to affect the spatial niche of some ectoparasites species on the host.

\section{ACKNOWLEDGMENTS}

We would like to thank Māris Nitcis of the Institute of Life Sciences and Technology, Daugavpils University for creating the map.

\section{REFERENCES}

Aldridge, D. C., McIvor, A. L. (2003). Gill evacuation and release of glochidia by Unio pictorum and Unio tumidus (Bivalvia: Unionidae) under thermal and hypoxic stress. J. Mollus. Stud., 69, 55-59.

Algers, B., Blokhuis, H. J., Bøtner, A., Broom, D. M., Costa, P., Domingo, M., Greiner, J., Hartung, F., Koenen, C., Müller-Graf, C., Morton, D., Osterhaus, A., Dirk, U. P., Raj, M., Roberts, R., Sanaa, M., Salman, M., Sharp, J. M., Vannier, P., Wierup, M. (2009). Scientific opinion of the panel on animal health and welfare on a request from the European Commission on welfare aspects of the main systems of stunning and killing of farmed eel (Anguilla anguilla). EFSA J., 1014, 1-42.

Barnard, K., Krasnov, B., Goff, L., Matthee, S. (2015). Infracommunity dynamics of chiggers (Trombiculidae) parasitic on a rodent. Parasitology, 142, 1605-1611

Bauer, O. N. (Ed.) (1987). Identification Key to Parasites of Freshwater Fish USSR. Nauka, Leningrad. 583 pp. (in Russian).

Billiard, S. M., Khan, R. A. (2003). Chronic stress in cunner, Tautogolabrus adspersus, exposed to municipal and industrial effluents. Ecotoxicol. Environ. Safety, 55, 9-18.

Blažek, R., Jarkovskż, J., Koubkovi, B., Gelnar, M. (2008). Seasonal variation in parasite occurrence and microhabitat distribution of monogenean parasites of gudgeon Gobio gobio (L.). Helminthologia, 45, 185-191.

Cardon, M., Loot, G., Grenouillet, G., Blanchet, S. (2011). Host characteristics and environmental factors differentially drive the burden and pathogenicity of an ectoparasite: A multilevel causal analysis. J. Anim. Ecol., 80, $657-667$

Chapman, L. J., Lanciani, C. A., Chapman, C. A. (2000). Ecology of a diplozoon parasite on the gills of the African cyprinid Barbus neumayeri. Afr. J. Ecol., 38, 312-320.

Davies, T. D. (2007). Sulphate toxicity to the aquatic moss, Fontinalis antipyretica. Chemosphere, 66, 444-451.

Dogel, A. V. (1962). General Parasitology. Leningrad State University, Leningrad. 463 pp. (in Russian)

Faul, F., Erdfelder, E., Buchner, A., Lang, A.-G. (2009). Statistical power analyses using $\mathrm{G}^{*}$ Power 3.1 : Tests for correlation and regression analyses. Behav. Res. Meth., 41, 1149-1160.
Faul, F., Erdfelder, E., Lang, A.-G., Buchner, A. (2007). G*Power 3: A flexible statistical power analysis program for the social, behavioral, and biomedical sciences. Behav. Res. Meth., 39, 175-191.

Faulkner, B. C., Lochmiller, R. L. (2000). Ecotoxicity revealed in parasite communities of Sigmodon hispidus in terrestrial environments contaminated with petrochemicals. Environ. Pollut., 110, 135-145.

Gilbert B. M., Avenant-Oldewage A. (2017). Parasites and pollution: the effectiveness of tiny organisms in assessing the quality of aquatic ecosystems, with a focus on Africa. Environ. Sci. Pollut. Res. Int., 24, 18742-18769.

Gussev, A. V. (1985). Identification Key to Parasites of Freshwater Fish of USSR. Nauka, Leningrad. 424 pp. (in Russian).

Harvell C. (1999). Emerging marine diseases-climate links and anthropogenic factors. Science, 285, 1505-1510.

Harvell C. (2002). Climate warming and disease risks for terrestrial and marine biota. Science, 296, 2158-2162.

Hutchinson G. (1957). Concluding remarks. Cold Spring Harb. Symp. Quant. Biol., 22, 415-427.

Jackman, S. (2015). pscl: classes and methods for R developed in the political science computational laboratory, Stanford University. Department of Political Science, Stanford University. Stanford, California. R package version 1.4.9. Available from: http://pscl.stanford.edu/

Johnson, P. T. J., Chase, J. M., Dosch, K. L., Gross, J. A., Hartson, R. B., Larson, D. J., Sutherland, D. R., Carpenter, S. R. (2007). Aquatic eutrophication promotes pathogenic infection in amphibians. Proc. Natl. Acad. Sci. U. S. A., 104, 15781-15786.

Khidr, A. A., Said, A. E., Abu Samak, O. A., Abu Sheref, S. E. (2012). The impacts of ecological factors on prevalence, mean intensity and seasonal changes of the monogenean gill parasite, Microcotyloides sp., infesting the Terapon puta fish inhabiting coastal region of Mediterranean Sea at Damietta region. J. Basic Appl. Zool., 65, 109-115.

Krebs, C. J. (1998). Niche measures and resourse preferences. In: Ecological Methodology. Addison - Welsey Education Publishers Inc., New York, pp. 597-653

Krieger, D. A., Terrell, J. W., Nelson, P. C. (1983). Habitat suitability information: yellow perch. U.S. Fish Wildl. Serv. FWS/OBS-83/10.55. 37 pp. Available from: https://www.nwrc.usgs.gov/wdb/pub/hsi/hsi-055.pdf (accessed 16.07.2018).

Kutty, M. N. (1987). Site selection for aquaculture: chemical future of water African Regional Aquaculture Centre Work. Pap. ARAC/87/WP/(29).

Lamková, K., Šimková, A., Palíková, M., Jurajda, P., Lojek, A. (2007). Seasonal changes of immunocompetence and parasitism in chub (Leuciscus cephalus), a freshwater cyprinid fish. Parasitol. Res., 101, 775-789.

Lefcort, H., Aguon, M. Q., Bond, K. A., Chapman, K. R., Chaquette, R., Clark, J., Kornachuk, P., Lang, B. Z., Martin, J. C. (2002). Indirect effects of heavy metals on parasites may cause shifts in snail species compositions. Arch. Environ. Contam. Toxicol., 43, 34-41.

Majumder, S., Panda, S., Bandyopadhyay, P. K. (2013). Effect of temperature on the prevalence of different parasites in Cirrhinus mrigala Hamilton of West Bengal. J. Parasit. Dis., 1-3.

Marcogliese D. (2008). The impact of climate change on the parasites and in fectious diseases of aquatic animals. Proc. Natl. Acad. Sci. U.S.A., 27, $467-484$.

Morand, S., Krasnov, B. R. (2010). The Biogeography of Host-parasite Interactions. Oxford University Press, Oxford. 288 pp.

Morand, S., Krasnov, B. R., Littlewood, D. T. J. (2015). Parasite Diversity and Diversification: Evolutionary Ecology Meets Phylogenetics. Cambridge University Press. 488 pp.

Moulder, J. W. (1950). The oxygen requirements of parasites. J. Parasitol., 36, 193-200. 
Öztürk, M. O., Altunel, F. N. (2006). Occurrence of Dactylogyrus infection linked to seasonal changes and host fish size on four cyprinid fishes in Lake Manyas, Turkey. Acta Zool. Acad. Sci. Hung., 52, 407-415.

Pilosof, S., Lareschi, M., Krasnov, B. (2012). Host body microcosm and ectoparasite infracommunities: arthropod ectoparasites are not spatially segregated. Parasitology, 139, 1739-1748.

Poulin, R. (2004). Macroecological patterns of species richness in parasite assemblages. Basic Appl. Ecol., 5, 423-434.

Poulin, R. (2008). Evolutionary Ecology of Parasites. Princeton University Press. 360 pp.

Retief, N., Avenant-Oldewage, A., Preez du H. H. (2007). Ecological aspects of the occurrence of Asian tapeworm, Bothriocephalus acheilognathi Yamaguti, 1934 infection in the largemouth yellowfish, Labeobarbus kimberleyensis (Gilchrist and Thompson, 1913) in the Vaal Dam, South Africa. Phys Chem Earth, 32, 1384-1390.

Rohde, K. (1991). Intra- and interspecific interactions in low density populations in resource-rich habitats. Oikos, 60, 91-104.

Saunders, L. M., Tompkins, D. M., Hudson, P. J. (2000). The role of oxygen availability in the embryonation of Heterakis gallinarum eggs. Int. J. Parasitol., 30, 1481-1485.

Shen, Z., Niu, J., Wang, Y., Wang, H., Zhao, X. (2013). Distribution and Transformation of Nutrients and Eutrophication in Large-scale Lakes and Reservoirs. Zhejiang University Press. 183 pp.

Siddall, R., Koskivaara, M., Valtonen, E. T. (1997). Dactylogyrus (Monogenea) infections on the gills of roach (Rutilus rutilus L.) experimentally exposed to pulp and paper mill effluent. Parasitology, 114, 439-446.

Simková, A., Desdevises, Y., Gelnar, M., Morand, S. (2000). Co-existence of nine gill ectoparasites (Dactylogyrus: Monogenea) parasitising the roach (Rutilus rutilus L.): History and present ecology. Int. J. Parasitol., 30, 1077-1088.

Received 24 November 2017

Accepted in the final form 16 January 2018

Published online 30 July 2018
Smallbone, W., Cable, J., Maceda-Veiga, A. (2016). Chronic nitrate enrichment decreases severity and induces protection against an infectious disease. Environ. Int., 91, 265-270.

Smith, V. H., Jones, T. P., Smith, M. S. (2005). Host nutrition and infectious disease: An ecological view. Front. Ecol. Environ., 3, 268-274.

Sulman, S. S. (1984). Identification Key to Parasites of Freshwater Fish of USSR. Nauka, Leningrad. 428 pp. (in Russian).

Sures, B., Nachev, M., Selbach, C., Marcogliese, D. J. (2017). Parasite re sponses to pollution: what we know and where we go in 'Environmental Parasitology'. Parasites Vectors, 10, 1-19.

Tidrikis, A. (1998). Sila ezers [Lake Sila]. In: Latvijas daba. Preses nams, Rīga, p. 92 (in Latvian).

Vaquer-Sunyer, R., Duarte, C. M. (2008). Thresholds of hypoxia for marine biodiversity. Proc. Natl. Acad. Sci., 105, 15452-15457.

Vidal-Martínez, V., Pech, B., Sures, B., Purucker, S., Poulin, R. (2010). Can parasites really reveal environmental impact? Trends Parasitol., 26, 44-51.

Wali. A., Balkhi, M. H., Maqbool, R., Darzi, M. M., Shah, F. A., Bhat, F. A., Bhat, B. A. (2016). Distribution of helminth parasites in intestines and their seasonal rate of infestation in three freshwater fishes of Kashmir. $J$. Parasitol. Res., 1-16.

Willmer, P., Stone, G., Johnston, I. (2004). Environmental Physiology of Animals. Wiley-Blackwell Press. 768 pp.

Yeomans, W. E., Chubb, J. C., Sweeting, R. A. (1997). Use of protozoan communities for pollution monitoring. Parassitologia, 39, 201-212.

Zhou, Y. (1989). The Problems of Sulphur: Reviews in Coal Science. IEA Coal Research, London. 354 pp.

Zolovs, M., Deksne, G., Daukšte, J., Aizups, J., Kirjušina, M. (2016) Morphometric analysis of the hard parts of Pseudodactylogyrus anguillae and Pseudodactylogyrus bini (Monogenea: Dactylogyridae) on the gill apparatus of the European eels (Anguilla anguilla) from the freshwaters of Latvia. J. Parasitol., 102, 388-394.

Zuur, A., Ieno, E. N., Walker, N., Saveliev, A. A., Smith, G. M. (2009). Mixed Effects Models and Extensions in Ecology with R. Springer Science Business Media, New York, USA. 574 pp.

\section{ASARU (PERCA FLUVIATILIS) EKTOPARAZĪTU TELPISKAIS SADALĪJUMS UN ŪDENS KIIMISKO KVALITĀTES PARAMETRU IETEKME UZ EKTOPARAZİTU TELPISKO NIŠAS LIELUMU}

Abiotisko faktoru sezonālās izmaiṇas un to ietekme uz parazītu sastopamību ir plaši pētìta. Lielākā dala pētījumu ir veikti, lai novērtētu ūdens fizikāli ḳimisko parametru ietekmi uz dažu parazîtu sugu intensitātes, ekstensitātes un komponentu sabiedrības izmaiṇām. Tomēr nepietiekama uzmanība tika veltīta saiknei starp ūdens kvalitātes parametriem un ektoparazītu telpisko nišu. Šajā darbā tika pētītas ektoparazītu lokalizācijas vietas uz asara (Perca fluviatilis L.), lai noskaidrotu, vai ūdens kvalitātes parametru sezonālas izmainas ir saistîtas ar ektoparazītu telpiskās nišas lielumu. Tika mērīta fosfātu $\mathrm{PO}_{4}^{3-}$, nitrātu $\mathrm{NO}_{3}^{-}$, sulfātu $\mathrm{SO}_{4}^{2-}$ un izškīiušā skābekḷa (DO) koncentrācija Sila ezerā (Latvija) katru mēnesi visa gada garumā, un no asariem tika ievākti ektoparazīti. Statistiskajai analīzei izmantoti zero-inflated jauktie modeli, lai novērtētu, kuri ūdens parametri ietekmē ektoparazītu telpiskās nišas lielumu. Mūsu rezultāti parādīja, ka dažu ektoparazìtu sugu telpiskās nišas lielumus ietekmē ūdens kvalitātes parametru kopums, un šis efekts ir negatīvs. Dižās bezzobes Anodonta cygnea glohīdiju telpiskās nišas lielums ir negatīvi saistīts ar fosfātu, nitrātu, sulfātu un izšķīiušā skābekḷa koncentrāciju. Trematodes Ancyrocephalus percae telpiskās nišas lielums ir negatīvi saistīts ar sulfātu koncentrāciju, un airkājvēža Ergasilus sieboldi telpiskās nišas lielums ir negatīvi saistīts ar nitrātu koncentrāciju. 